\title{
Nordic masters
}

After recording the death of Jørn Utzon in our last issue, in this we carry an obituary for Sverre Fehn (pp. 11-15), and with it the feeling that their passing marks the end of an era. True, Oscar Niemeyer is still designing at more than 100 years of age, but Utzon and Fehn represented a living link to the mainstream of postwar Modern Architecture in Europe in a way that Niemeyer, despite his sojourn in Paris, never could. As young architects in the early 1950s both Utzon and Fehn revered Le Corbusier and Mies at a time when the Corbusian and Miesian strands of Modern architecture were widely seen as antithetical, and both went on to develop compelling new syntheses that melded Le Corbusier's poetic vision with a Miesian commitment to clarity of tectonic expression.

Although, with their shared commitment to making construction the basis of architectural expression, Utzon and Fehn were by no means typical of the more designerly Scandinavian tradition, in their belief in architecture as a quintessentially social art they most certainly were. And in this they invite us to ponder again why a group of countries (if one includes Finland) whose population totals roughly half that of the UK should have given us a succession of major talents - in order of birth, Lewerentz, Asplund, Aalto, Utzon - and a host of hugely gifted other figures from Jacobsen to Fehn.

It is clearly a matter of culture, not chance. As George Kubler observes in The Shape of Time, 'times and opportunities differ more than the degree of talent' - for a budding painter, choosing to be born in fifteenth century Florence or mid-nineteenth century France was astute. The architecture-inspiring virtues of the Nordic countries are familiar: challenging climates that encourage a rare combination of realism and reverie; a level of respect for architecture as a profession that has not, to put it mildly, been so apparent in the Anglo-Saxon world; a healthy competition system for public buildings; an early and distinctive commitment to social democracy and pioneering of social values and practices that are now widespread elsewhere; a strong tradition of architectural education in which leading architects have consistently occupied central roles; and a love of 'the nature' that has acted as a counterpoint to modernity's preoccupation with technology and provided a locus for both national sentiment and family life.

Timing was equally vital: both Utzon and Fehn were born early enough to share in the continuity of the Modern Movement, but late enough to contribute to the post-war re-evaluation of its early ideals. Unlike many of their contemporaries in Denmark and Norway, however, they did not benefit greatly from the boom in public commissions during the 1950 os and ' 60 , and while the soil in which they were educated may have been fertile, neither - for reasons of personality rather than talent - enjoyed the public support their abilities might have been expected to attract. Both were gentle men, keen to let their work speak for them, and as a consequence both needed patrons, not merely clients. But when the circumstances were propitious, as they were for Utzon working with Pastor Simonsen on the Bagsvaerd Church or for Fehn in designing the Nordic Pavilion for the Venice Biennale and the Hamar Museum, the resulting architecture achieved a clarity and poetic intensity that has rarely been rivalled since the death of Le Corbusier. 


\section{architectural research quarterly}

\section{Subscribe now for 2009}

Innovative in conception, unique in breadth and generously illustrated, this pace-setting quarterly publication from Cambridge University Press links, on a global scale, the worlds of architectural practice and research. arq regularly includes extensive peer-reviewed sections on design, history, theory, construction, environmental design, information technology and practice - as well as structures, urbanism and documents. These are supplemented by letters, reports, reviews, a directory of specialist research centers and consultancies and an annual index. Each issue opens with a leader and closes with insight, a personal end-piece. In its ten year history, arq has published work from all over the world: from Chile to Sweden and from Japan to the Netherlands - with a strong representation from the United Kingdom and United States. arq, like architecture itself, is all-embracing and written by and for both practitioners and academics. It provides an outlet for all those who wish to disseminate their work to an international audience.
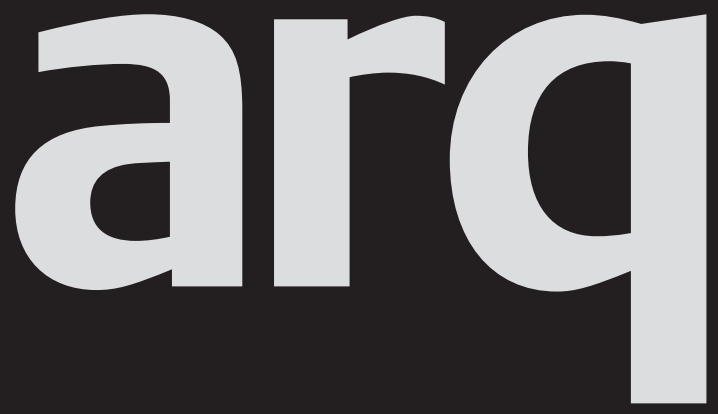

Please enter my subscription to arq: architectural research quarterly, volume 13, 2009 $\square$ E186/\$308 institutions print and electronic $\square E_{30} / \$ 50$ students print only

$\square$ £42/\$64 individuals print only

EU residents only. VAT may be payable at your local rate if not registered.

Our VAT registration number: GB 214141614 If registered, your VAT registration no:

Total subscription payment $£ / \$$ EU residents only, if not registered add VAT at appropriate rate

Canadian residents, add 7\% GST \$

Name

Total $\mathbf{E} / \mathbf{\$}$

Address

Payment enclosed

Cheque in sterling or US dollars

(payable to Cambridge University Press)

Credit Card - VISA | MasterCard | American Express (delete where applicable)

Card no

Expiry date

Signature

Photocopy this page and send your order to:

Journals Customer Services, Cambridge University Press, The Edinburgh Building, Cambridge, CB2 8RU, UK

T $+44(0) 1223326070$

$\mathrm{F}+44(0) 1223315052$

E journals@cambridge.org

or in USA, Canada and Mexico send to:

Cambridge University Press, 32 Avenue of the

Americas, New York NY 10013-2473, USA

T (914) 9379600

F (914) 9374712

E journals_subscriptions@cup.org 